\title{
LAND CAPABILITY EVALUATION OF FORMER BAUXITE MINING LAND FOR LAND USE PLANNING BY INTEGRATING REMOTE SENSING AND GEOGRAPHIC INFORMATION SYSTEM IN SANGGAU WEST KALIMANTAN INDONESIA
}

\author{
AJUN PURWANTO* AND DONY ANDRASMORO \\ Departement of Geography Education, IKIP PGRI Pontianak, West Kalimantan. \\ *Corresponding author: ajunpurwanto@ikippgriptk.ac.id \\ Submitted final draft: 16 June $2020 \quad$ Accepted: 25 July 2020
}

http://doi.org/10.46754/jssm.2021.08.019

\begin{abstract}
The bauxite mining activities at Sejotang village, Sanggau district West Kalimantan Province caused siltation of lake, the loss of fish habitat, erosion, forest destruction and the loss of basic livelihoods. This study aimed to determine the class of land capability as well as the land use planning of the former bauxite mining. Methods used namely Landsat 8 satellite image interpretation in 2011-2016, Digital Elevation Model image from DEMNAS Badan Informasi Geospasial (BIG), and ground survey. Data analysis in this study used Geographic Information System (GIS) and Land Capability Land Planning (LCLP) software. The study found that area has III-VI land capability class. Class III land capability has limiting factors of the flood, and gravel. Class IV land capability has limiting factors the landslide, slope, erosion rate, gravel, and drainage. Class V land capability has limiting factors of gravel and permeability. While class VI has soil depth limiting factor. Class III and IV land capability are possible to be used for seasonal crops such as agriculture or plantation, pastures, production forest, protected forests, or wildlife sanctuaries. Meanwhile, Class V and VI cannot be cultivated or processed for agriculture. However, these classes can be utilized as pastures and be shepherding production forests, protected forests, or nature reserves.
\end{abstract}

Keywords: Land capability, bauxite mining, land use, remote sensing, geographic information system.

\section{Introduction}

Mining activities cause adverse impacts on the land. Examples of such mining activities include coal mining, gold, nickel, tin and many more. One of the mining activities is bauxite mining. These impacts could be found in the former bauxite mining land in Sejotang village, Sanggau district West Kalimantan Province. Bauxite mining activities bring about environmental destruction, siltation of the lake, the loss of fish habitat, open soil and thus these things give rise to moisture erosion and surrounding environment (forest) damage as well as the loss of basic livelihood of the surrounding community. The major devastation to the land could degrade the land quality and increase in heavy metal concentrations in the ecosystem (Hashim et al., 2018).

Land degradation has many negative effects. The negative effects among others environmental quality degradation and destruction of natural resources (Mamat et al., 2016), reduced land capacity, the loss of ecosystem productivity, shifts in vegetation composition, and the loss of rural livelihoods (D’Odorico \& Ravi, 2016), strengthening social and political weaknesses that can also contribute to the threat of illegal migration, transboundary conflicts and the other forms of violence in survival (Barbut \& Alexander, 2016) and negatively impact on sustainable development (Barbut \& Alexander, 2016; Zambon et al., 2017). Declining land quality is a very serious problem which can decrease the ability or carrying capacity of the land.

Former mine land, which has not been handled well, has the potential to be developed for various uses for instances agriculture, grasslands, and forests depend on the land quality (Skousen \& Zipper, 2014; Abdel Rahman, et 
al, 2016), biofuel plants, wildlife habitats and building site development (Skousen \& Zipper, 2014). Therefore, to develop the land, the land potential and classification of land capacity for proper use or planning should be carried out and identified (Kharche \& Gaikawad, 1993; Patel et $a l ., 2001)$ and also evaluation purposely created for land use planning (Armanto et al,, 2013).

Identification and classification of land capability can be executed using various approaches. Some of them are Remote Sensing and Geographical Information System (GIS) (Widiati et al, 2017). Remote Sensing and GIS are very useful and accurate tools for identifying various earth sources, potential, and processing spatial analysis (Razeena Beebi, 2015; Purwanto $\&$ Bayuardi, 2016). Through the remote sensing techniques, a variety of resource maps can be created with the help of GIS. This map can then be analysed to obtain composite maps with various information on diverse areas (Abdel Rahman et al., 2016). Remote Sensing data can be used for biophysical parameters, plant indices, land use estimates, and land cover at different times. Different time will provide different data information about the characteristics of the object from one year to the next (Panigrahy et al., 2005; Rao et al., 1996; Abdel Rahman et al., 2016). GIS can simultaneously transform spatial data as inputs to produce a decision (Kabanda, 2015) which involves an area in support of a particular land use (Qiu et al., 2014)

Land use planning for former mining land can be undertaken appropriately through an assessment of its land capability. Land tenure is a very important issue in terms of sustainable land use without permanent damage over long periods of time (FAO, 1983; Atalay, 2016). Land ability means the ability of the soil to support certain types of use without causing permanent destruction (Gad, 2015). Based on its capabilities or limitations, by Soil Conservation Service (1958, 1963) and (Kumar et al., 2017), land tenure classes are grouped into eight classes (class I to VIII). From these classes, the first four classes (class I to IV) of land can be used for agriculture or cultivation of crops. These four classes (class I to IV) are distinguished by soil slope, erosion, depth, structure, soil reaction, and drainage. While class V to VIII cannot support the cultivation of plants, but just for growing grass and forestry. The last four classes (class $\mathrm{V}$ to VIII) are described based on problems such as river flow, flood, inundation, bedrock and planting season (Abdel Rahman et al., 2016).

The classification of land capability provides a guidance for assessment of land constraints and land management, recommendations for multiple scales-use including country, catchment area, and for use planning (Murphy et al., 2004; Gad, 2015). Land use planning can be in the form of use for settlements, industry, tourism, parks and for reforestation and others.

The first classification of land capability was developed by Natural Resource Conservation Service in the late 1930s and early 1940s (Helms, 1997; Osman, 2014; Sinclair \& Dobos, 2006). There are three classifications of land capability namely: class capability, subclass capability, and unit capability. Land classes are grouped by landscape, slope, depth of soil, texture, and acidity. Subclasses have some limitations such as erosion, wet excess, root zone problems, and climate limitation. The land capability unit is identified as a grouping of land with the same level of results and general requirements for land management (Gad, 2015).

This research aimed to define the class, subclass of the land capability of the former bauxite mining land and provide land use planning for the former bauxite mining land.

\section{Materials and Methods}

\section{Study Area}

This research was conducted at the site of the former bauxite mining, located in Sejotang Village, Sanggau district, West Kalimantan Province, Indonesia. The area of study site is 93,628.7 Ha. Geographical this area is located between Longitude from $110^{\circ} 4^{\prime} 0$ " $\mathrm{E}$ to $110^{\circ} 5^{\prime} 0$ " E and Latitude $0^{\circ} 1{ }^{\prime} 30^{\prime \prime} \mathrm{S}$ to $0^{\circ} 20^{\prime} 30^{\prime \prime} \mathrm{S}$. For more details, the bauxite mining location can be seen in Figure 1. 


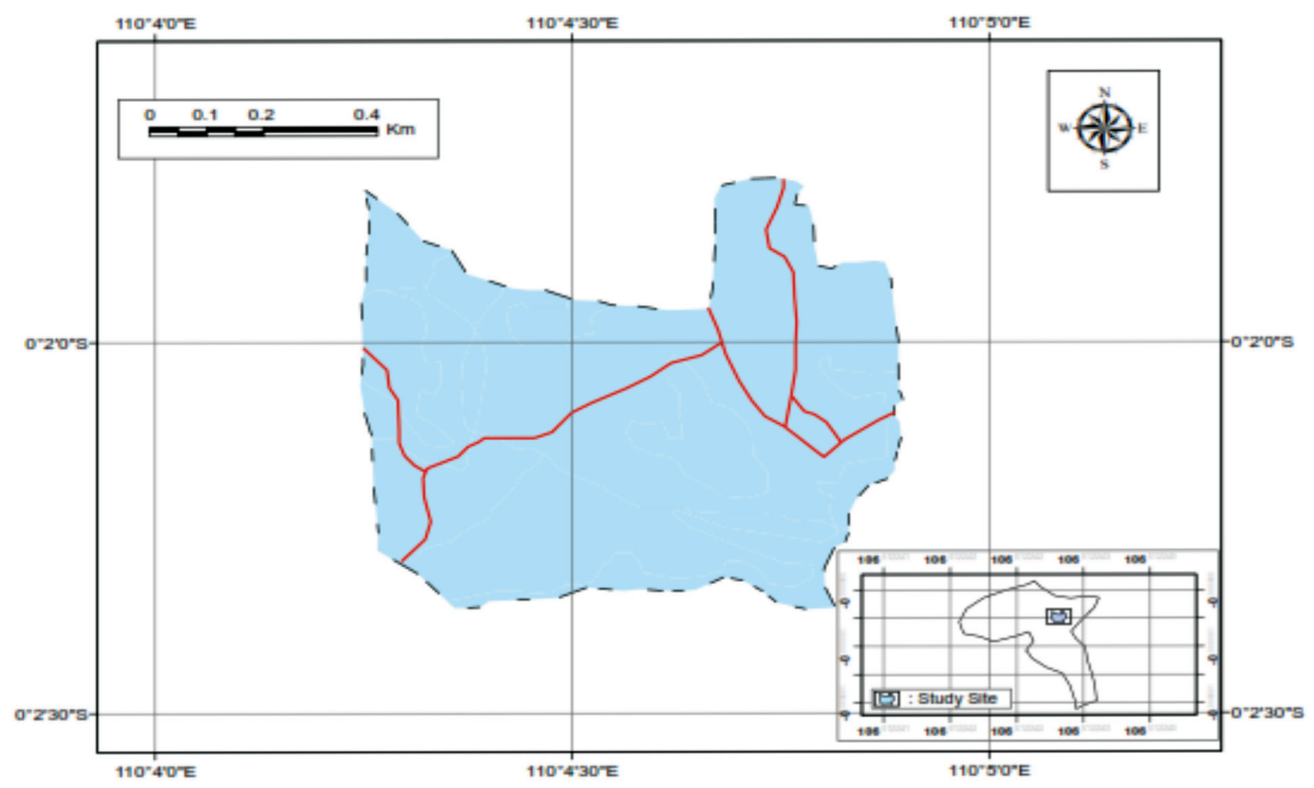

Figure 1: Study area

\section{Research Method}

The data that were used in the Soil Survey Staff (1959) classification wich consist of surface slopes, gravel/rock, top layer texture, permeability, bottom layer texture, soil depth, soil drainage, the dangers of erosion, erosion sensitivity, landslide, and flood threats. There is a parameter modification to assess the land capability class carried out on former mining land. The modification is the addition of one parameter of land capability, namely water availability capacity.

In addition to another data of land, there are two data required, namely Digital Elevation Model (DEM) whos taken from DEMNAS Badan Informasi Geospasial (BIG), for slope analysis and Landsat 8 to determine land use change and land damage. The variable of water availability capacity data should be added as it greatly influences soil density, soil strength, and rooting of plants before and after mining (USDA, 1983; Sinclair \& Dobos, 2006).
This work employed some methods namely Landsat image interpretation, DEM analysis, and soil surveys for sampling to be analyzed in the laboratory. Image interpretation was utilized to view temporal land use changes (Kanianska et al., 2014; Lillesand et al., 2015; Liu et al., 2017; Dube et al., 2017) pre and post activities. Temporal changes in land use of the study area pre and post activities activities can be seen in Figure 2 and Figure 3.

Interpretations were performed for Landsat 8 imagery in 2011 and 2016 and DEM images whose taken from DEMNAS Badan Informasi Geospasial (BIG), while ground survey were conducted to capture land characteristic data. The sampling method used in this research was purposive sampling (Sholihah, Utomo, \& Juarti, 2016; Utomo, 2016), with land strata. Land Capability Land Planning (LCLP) Software is used to analyse data. This analysis technique has also been used by Maryati, (2013) and Widiati et al. (2017). 


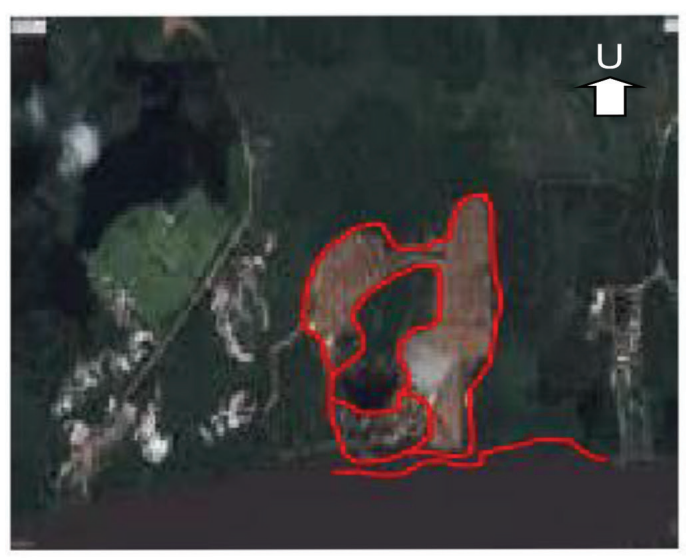

Figure 2: Mining sites in 2011

This research was conducted in three phases. The three phases are as follows.

\section{Phase 1: Preparation Phase}

This phase collected and studied secondary data, that were Landsat images, DEM, topographic map, geology map, soil map, and some theories and some theories such used scoring or matching in determining land capability classes.

\section{Phase 2: Landsat Sattelite Image Processing and Interpretation}

Stage 1

The first stage in Landsat satellite image processing and interpretation phase was multiyear Landsat interpretation of imagery available from 2011 and 2016. This data was utilized to determine the changes in land use and post mining areas.

\section{Stage 2}

The second stage in Landsat satellite image processing and interpretation phase was creating contour maps for the slope gradient (Mohd et al., 2019) obtained from the DEMNAS Badan Informasi Geospasial (BIG), which was processed using ArcGis.

\section{Stage 3}

The third stage in Landsat satellite image processing and interpretation phase was making

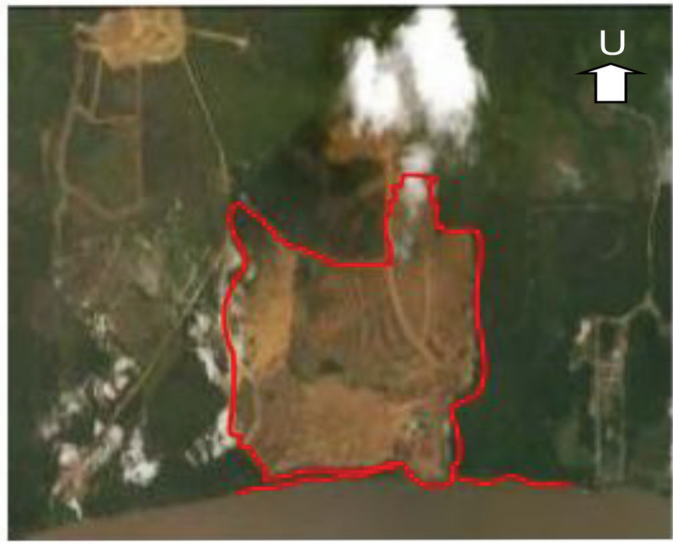

Figure 3: Mining sites in 2016

landform maps. Landform maps are made by overlapping the slope gradient maps with geological maps using ArcGIS

\section{Stage 4}

The fourth stage in Landsat satellite image processing and interpretation phase was creating the analysis unit map by overlapping landform map with soil map. The unit of analysis used in this research was the land unit.

\section{Phase 3: Field Check (Ground Truth) and Data Analysis}

Field checks were conducted directly to the supplement data such as type and structure of rock that could not be obtained in the Landsat image during the interpretation process. Field checks are based on determining Ground Control Points (GCP) (Purwanto \& Bayuardi, 2016). Data obtained from the results of the field survey were then analysed using LCLP software.

The use of GIS and Remote Sensing above is very helpful in this research, especially for land use planning. The use of GIS and Remote Sensing starting from planning, assisting in making the basic maps used, to the implementation in taking data at field and analysing data to produce research findings. 


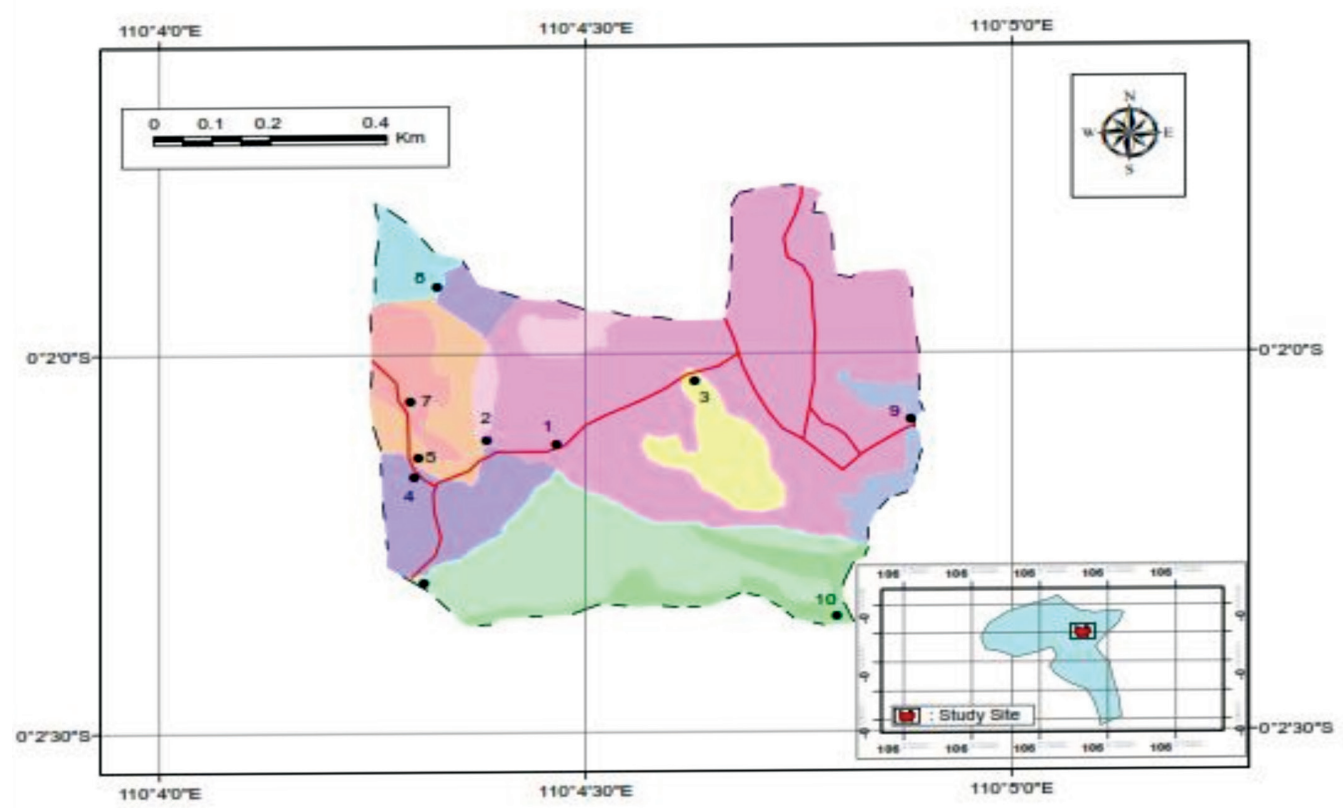

Figure 4: Ground control point

\section{Results and Discussion}

The results of this study include the landform former bauxite mining, the characteristics of each landform, and characteristics of the land capability parameters in the former bauxite mining site in the study area.

The study area has two forms of origin, i.e. denudational and fluvial origin. The denudational form of land consists of four units of landform, namely the form of denudational hills (D1), the upper slope of denudational hills granite lauric (D2), the middle slope of denudational hills granite lauric (D3) and the foot slope of denudational hills (D4). The form of the fluvial origin has one unit of landform, namely the form of alluvial plains (F2). The overlapping between the landform map and the soil map produces terrain unit maps. The observation results and measurement in the form of land characteristic and land quality of each land unit can be seen in Table 1.

The slope of the study area ranges from $0 \%$ $20 \%$ with flat topography to hilly. The distribution of gravel/rock ranges from none $(0.01 \%$ of total area) to many (15-90\% of total area). Top and subsoil texture ranges from smooth (clay) to medium (sandy clay); soil permeability is very slow to medium; water availability capacity ranges from 7.5-22.5 cm (very shallow-deep), poor soil drainage is marked part below the top layer; near the surface, there are colours or spots in grey, brown and yellowish. In addition to bad drainage, there is also a rather good, where there are no patches of yellow, brown or grey on the top layer and the top layer of the bottom to 60 $\mathrm{cm}$ from the ground.

The level of soil erosion ranges from none to moderately severe (more than $75 \%$ of the top layer to less than $25 \%$ of the undercoat is lost). The erodibility or easiness of eroded soils ranges from 0.00 to $10.10 \mathrm{~cm} / \mathrm{h}$ (very low) to 0.43 (moderately high). Landslides occur only mild to moderate i.e. the landslide on the land surface is about $14-20 \%$ of the affected area. Flood incident occurs only on the alluvial plains that occur for one month in one-year flood $>24$ hours. 


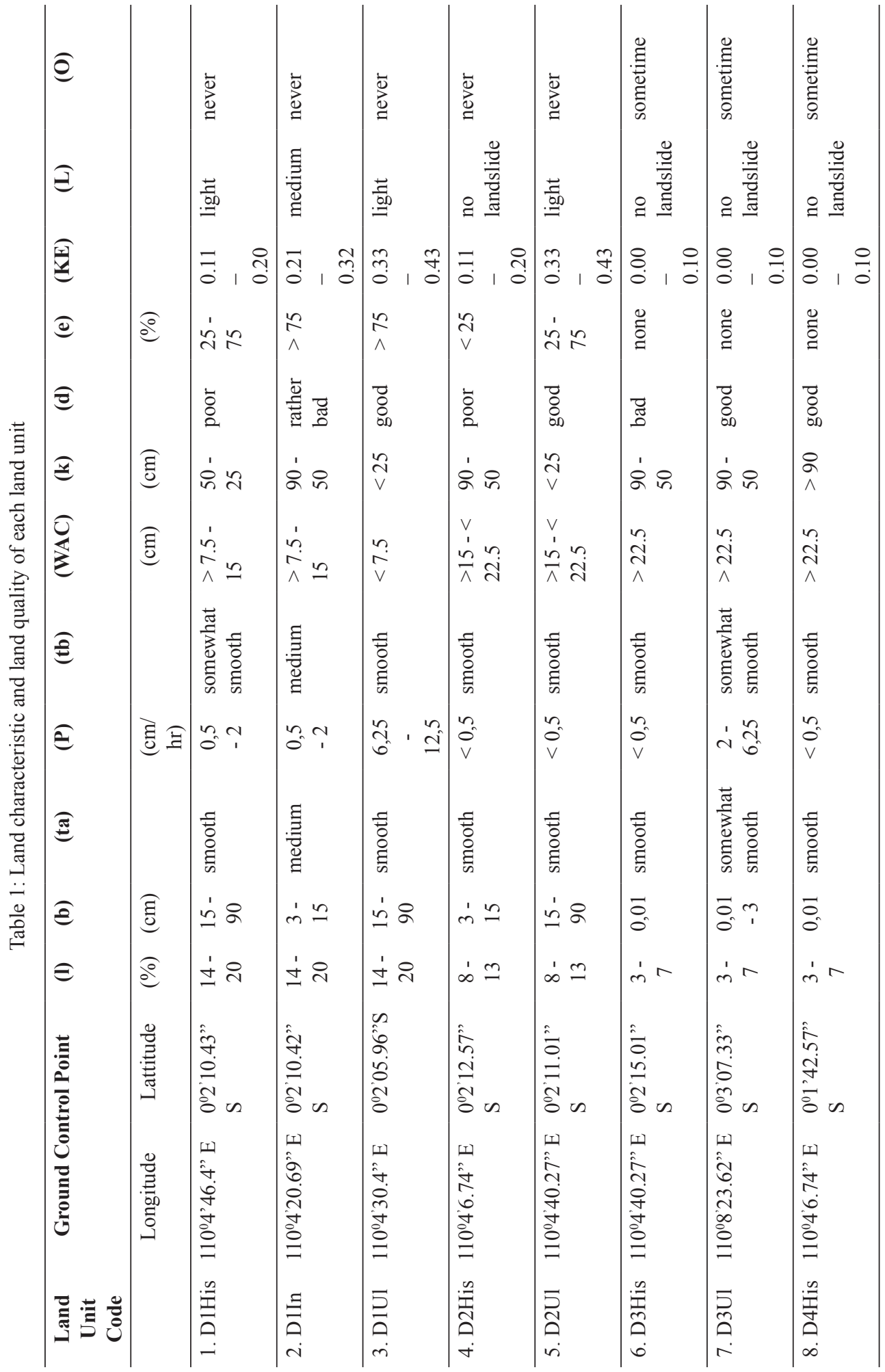




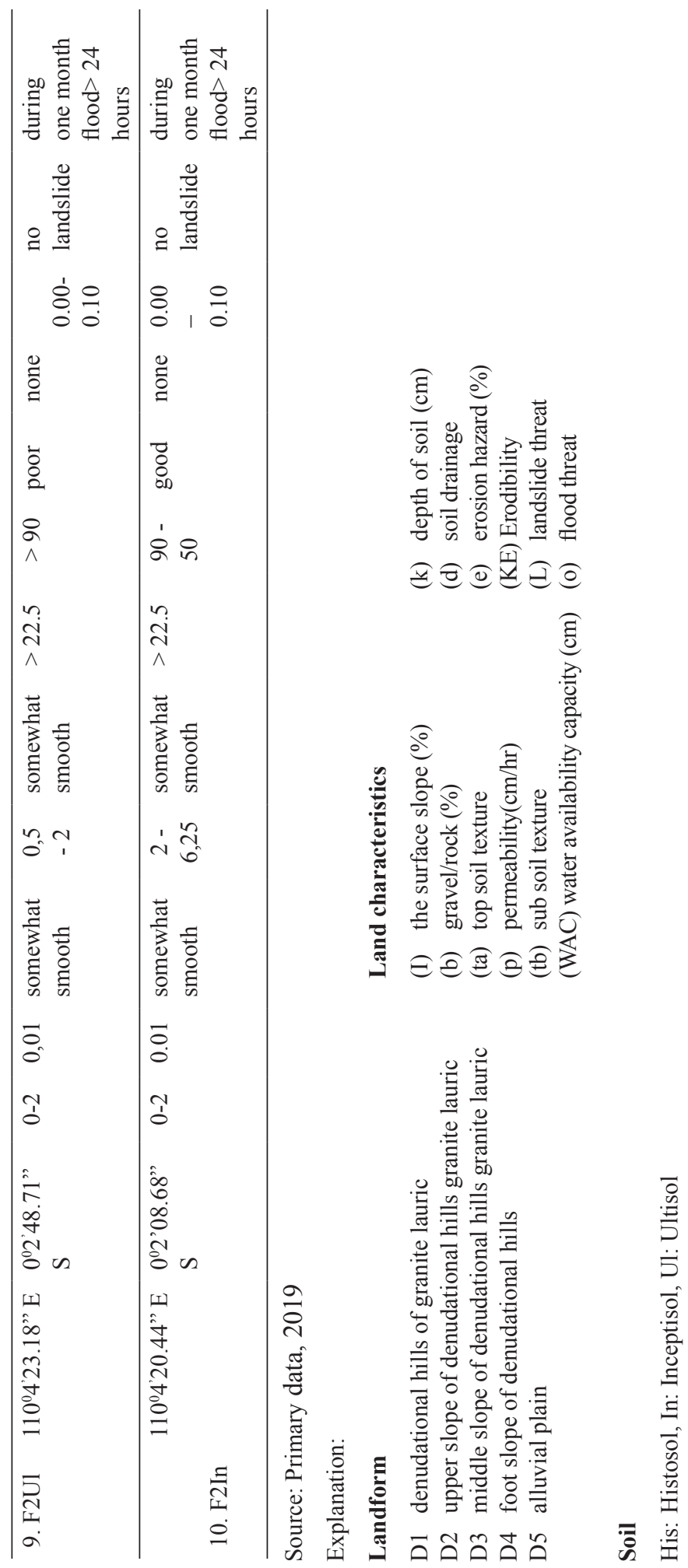


The parameters that were used for assessment of land capability in this research consist of 12 parameters categorized as three properties of soil, topographic, and hazard. These parameters obtained from field observations were also taken from remote sensing data. The parameters consist of top soil, subsoil, slope, drainage, soil depth, erosion rate, gravel/rock, flood, permeability, landslide, water available capacity, and soil erodibility. Water availability capacity is an additional parameter, so it is different from the previous land capability parameters. The land capability parameters, code, limit factor and limit factor category can be seen in Table 2 .

The description of limiting factor provides information concerning the classification of each parameter. The description of limiting factor of land capability can be seen in Figure 5.

Table 2: Land capability parameters taken from LCLP software

\begin{tabular}{lll}
\hline \multicolumn{1}{c}{ Code } & \multicolumn{1}{c}{ Limit Factor } & Limit Factor Catagory \\
\hline tb & Sub soil texture & \\
$\mathrm{d}$ & Drainage & \\
$\mathrm{k}$ & Soil depth & Soil \\
$\mathrm{b}$ & Gravel/ rock & \\
$\mathrm{p}$ & Permeability & \\
$\mathrm{ta}$ & Top soil texture & \\
$\mathrm{KKA}$ & Water Avaliabel Capacity & \\
$\mathrm{KE}$ & Erodibility & \\
\hline $\mathrm{e}$ & Erosion & \\
$\mathrm{o}$ & Flood & Hazard \\
$\mathrm{L}$ & Land Slide & Topography \\
\hline $\mathrm{I}$ & Slope & \\
\hline
\end{tabular}

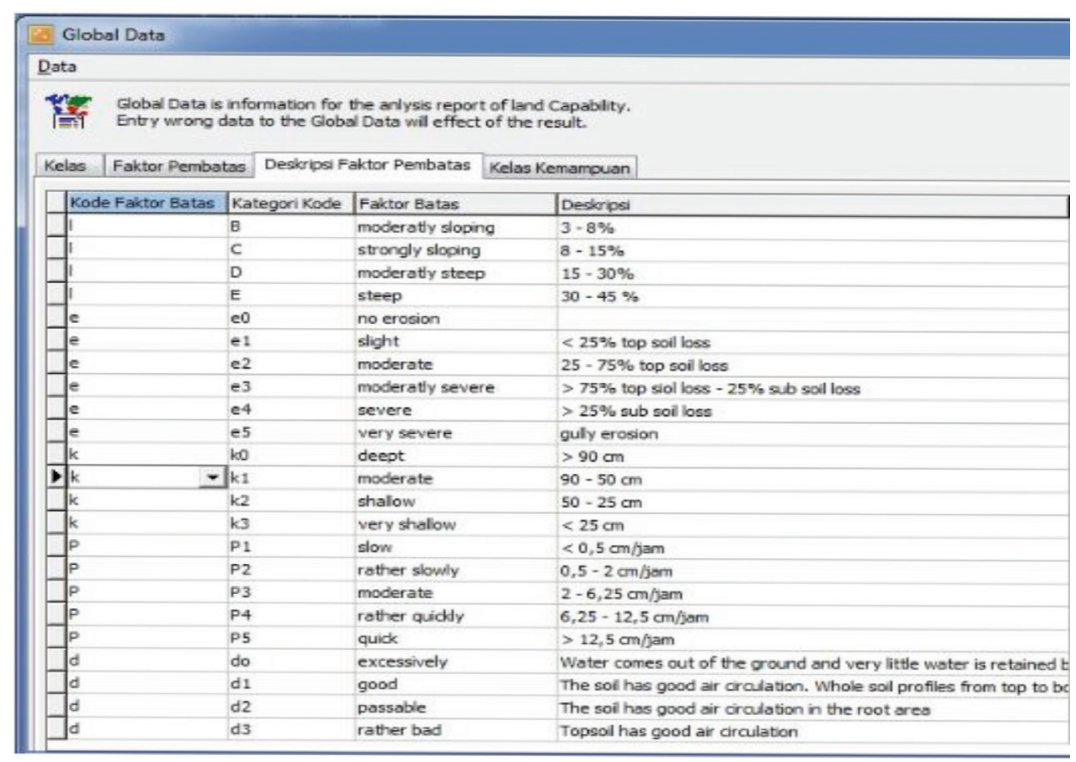

Figure 5. Description of limiting factor 
Data from field observations and image analyses are then analysed. This analysis used the Land Use Land Capability (LCLP) software. Data entered in the software is automatically processed and the results can be known immediately. The results of the analysis of soil characteristics and quality using LCLP software is that land capability in the study area can be classified into classes III-VI. The third class of land capability is located at the middle slope of denudational hills granite lauric (D3) and alluvial plains (F2). Class IV of land capability waste found in hilly denudational hills of granite lauric (D1) and alluvial plains (F2). The class V of land capability is located on the upper slope of denudational hills granite lauric (D2), the middle slope of denudational hills granite lauric (D3) and the foot slope of denudational hills (D4). The land capability class VI is scattered in units of denudational hills forming with granite lauric (D1) and denudational hillside slopes of granite lauric (D2).

The study area also has a subclass III of land capability with flood as the limiting factor and gravel/rock spreading over D3U1 and F2In land units. Subclass IV of land capability has landslide limiting factor, slope, erosion, gravel/ rock and drainage spreading over D1In and F2U1 land units. Subclass V of land capability has the limiting factor of gravel/rock and permeability spreading over the units of land D1His, D2His, D3His, and D4His. Subclass VI of land capability has soil depth limiting factor scattering in D1U1 and D2Ul land units. The classes and subclasses of the land capability in the study area can be seen in Table 3 and Figure 6.

The location of former bauxite mining with a land capability class III indicates that the land at that location can be cultivated or processed intensively. In this class, the land has subclass III-b, O. The subclass III-b with limiting factor of gravel/rock has an area of 4.910 ha $(6 \%)$ and the subclass III-O with limiting factor of flood has an area of 5.100 ha (6.4\%). This unit of land can be developed into an extensive agricultural area, so the cultivation system (or animals) only uses low capital and labour inputs, relative to the size of the land used.

Limiting factor in this unit of land can be fixed by moderate conservation measures. Limiting factor is the distribution of the gravel or surface rock factor which can be overcome

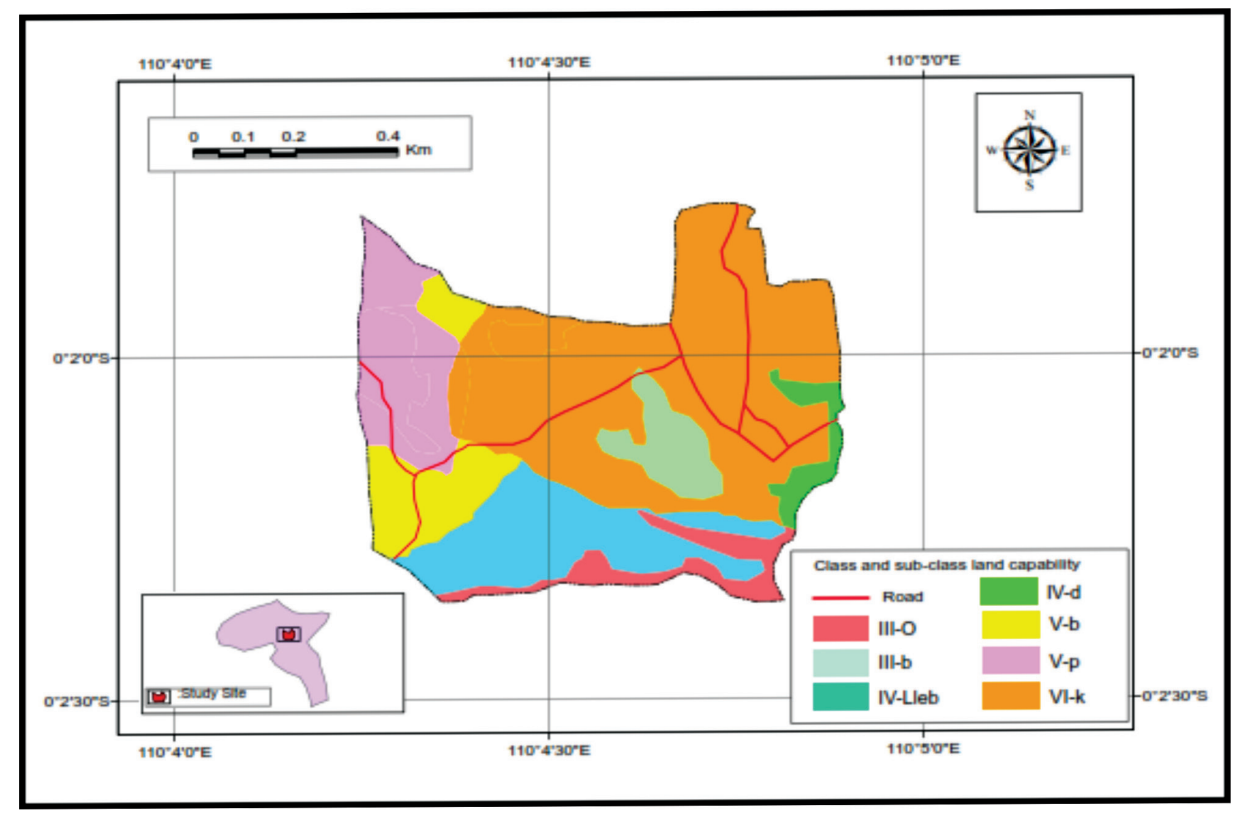

Figure 6: Classes and subclasses of land capability 
Table 3: Classes and subclasses of land capability of study areas

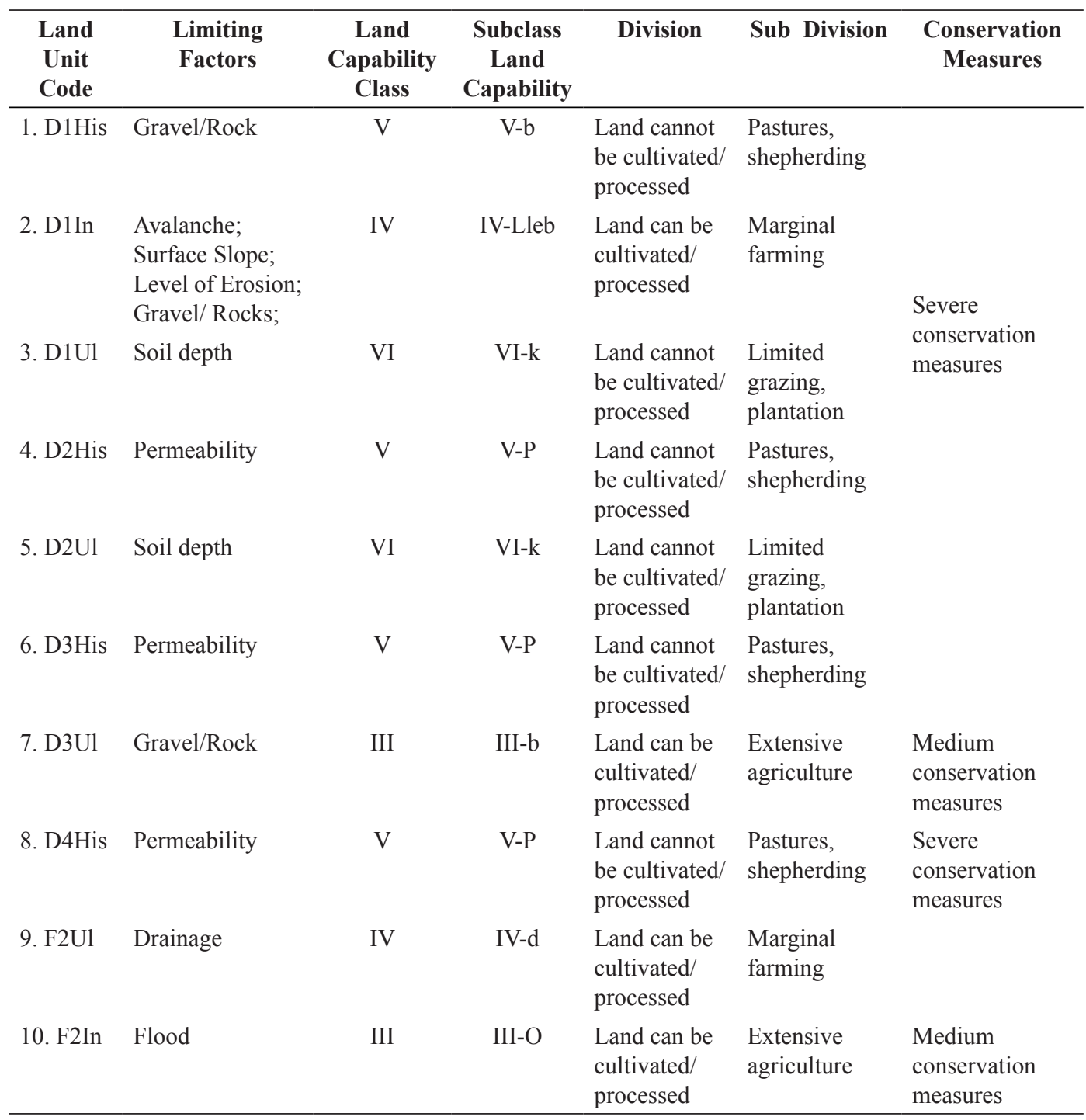

Source: Result of Primary Data Processing, 2019

by clearing the surface rock distribution. Flood factor can be shorted out by making good drainage so that the flood on these areas decreases. Good drainage plays a significant role in reducing excessive water, preventing flood and ground damage.

Land capability class IV indicates that the land can be cultivated or processed for agriculture, but it is very limited (marginal). The land in the capability class IV may be used for seasonal crops and the other general crops, grasses, production forests, pastures, protected forests or nature reserves (Klingebiel \& Montgomery, 1961; Arsyad, 2010; Maryati, 2013; Osman, 2014). In this class, the land has a land capability subclass IV-Lleb,d. The limiting factors consist of landslide, large slope inclination, high erosion rate, and rocks which have an area of 15.144 ha $(18.52 \%)$ and drainage limiting factor having an area of 2.632 
ha $(3.22 \%)$. These limiting factors are very heavy and require good conservation measures.

Conservation can be executed mechanically and specifically by making a bench terrace, tilling the soil according to the contour line to prevent erosion and landslide, and making vegetation channel fora good air aeration process in soil. In addition to the mechanical action, it is necessary to maintain the fertility and physical condition of the soil with the planting of ground cover crops. This planting aims to improve soil structure, increase organic material, and prevent nutrient leaching.

However, in the cultivation of crops and their use, the cost was greater than class III. The land capability class IV and sub-class IVLleb,d require more serious effort in handling the limiting factors mentioned above namely moderate landslide, large slope inclination, high erosion rate, moderate rock and rocks, and drainage (Arsyad, 2010; Maryati, 2013; Osman, 2014).

Land capability class $\mathrm{V}$ means that the land cannot be cultivated or processed. In this class, the land in the study area has a subclass $\mathrm{V}-\mathrm{b}, \mathrm{p}$ capability. The limiting factors consist of gravel/rock and soil permeability. The subclass V-b has an area of 86 ha $(0.11 \%)$ and subclass V-p has an area of 9.282 ha (11.35\%). The land cannot be cultivated so it should be used for the other purposes such as pastures and cultivation, production forests, and protected forests or nature reserves (Arsyad, 2010; Maryati, 2013; Osman, 2014). If it is used for production forest, it is necessary to plant crops that have a high economic value in accordance with the local conditions.

Land capability class VI has similar consequences with land capability class V. Land capability class VI cannot be cultivated or processed. The land at the former mining site has a subclass VI-k having limiting factor of soil depth with an area of 44.631 .9 ha (54.57\%). The land cannot be cultivated or processed and should be used for limited grazing and plantation. The land use for plantations should be for producing the plants that have a high economic value so that people can still use the land. However, in addition to both purposes, the land can be utilized for production forest, protected forest or nature reserves (Arsyad, 2010; Maryati, 2013; Osman, 2014). The land use planning of bauxite mining sites can be seen in Figure 7.

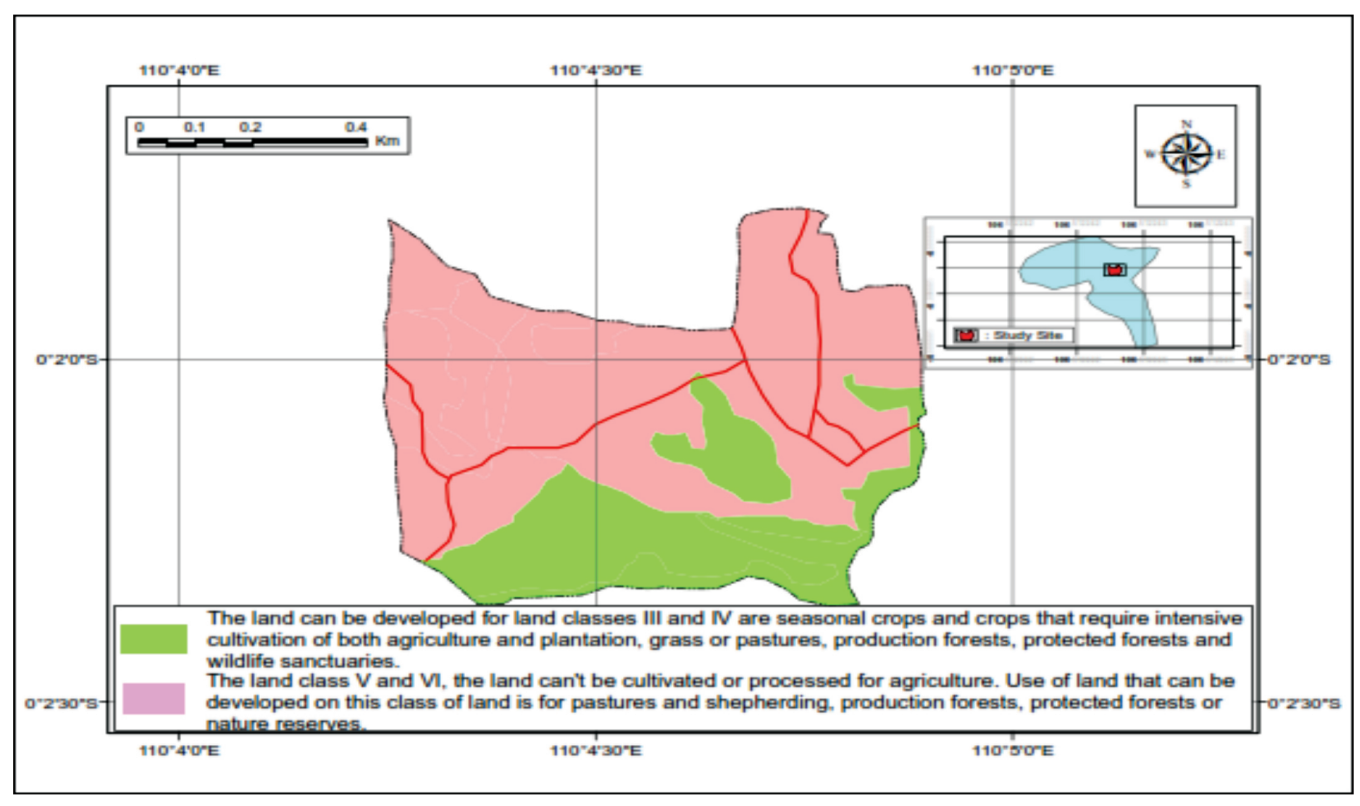

Figure 7: Land use planning of former mining land 


\section{Conclusion}

The results and discussion of this research show that the study area has the capability class III to VI. The study area also has a land capability subclass III with flood limiting factor and the spread of gravel/rock over D3Ul and F2In land units. Land capability subclass IV has the limiting factors of landslide, slope, erosion rate, gravel/rock and drainage spreading over D1In and F2U1 land units. The land capability class III and IV have an area of 27.786 ha $(33.97 \%)$ that can be developed for seasonal crops and crops that require intensive cultivation of both agriculture and plantation, grass or pastures, production forests, protected forests, and wildlife sanctuaries.

Subclass V of land capability has the limiting factors of gravel/rock and permeability spreading over the unit of land D1His, D2His, D3His, and D4His. The subclass VI of land capability has soil depth limiting factor spreading over D1U1 and D2U1 land units. The land capability of class V and VI have an area of 54.001 ha $(66.03 \%)$, the land cannot be cultivated or processed for agriculture. The land use that can be developed in this class of land is for pastures and shepherding, production forests, protected forests or nature reserves.

\section{Acknowledgements}

The authors would like to thank the Mining and Mineral Resources of West Kalimantan Province, Land Rehabilitation and Soil Conservation Department of Forestry West Kalimantan Province that has provided the data on land use and other research facilities.

\section{Refferences}

Abdel Rahman, M. A. E., Natarajan, A., \& Hegde, R. (2016). Assessment of land suitability and capability by integrating remote sensing and GIS for agriculture in Chamarajanagar district, Karnataka, India. The Egyptian Journal of Remote Sensing and Space Science, 19(1), 125-141.
Armanto, M., Adzemi, M. A., Wildayana, E., \& Imanudin, M. S. (2013). Land evaluation for paddy cultivation in the reclaimed tidal lowland in Delta Saleh, South Sumatra Indonesia. Journal of Sustainability and Management, 8 (1), 32-42.

Arsyad, S. (2010). Konservasi tanah dan air. Bandung: IPB Press.

Atalay, I. (2016). A new approach to the land capability classification: Case study of Turkey. Procedia Environmental Sciences, 32, 264-274.

Barbut, M., \& Alexander, S. (2016). Land degradation as a security threat amplifier: The new global frontline. Land Restoration, 3-12.

D’Odorico, P., \& Ravi, S. (2016). Land degradation and environmental change. $J$. Biological and Environmental Hazards, Risks, and Disasters, 219-227. https://doi. org/10.1016/b978-0-12-394847-2.00014-0.

Dube, T., Mutanga, O., Sibanda, M., Seutloali, K., \& Shoko, C. (2017). Use of landsat series data to analyse the spatial and temporal variations of land degradation in a dispersive soil environment: A case of King Sabata Dalindyebo local municipality in the Eastern Cape Province, South Africa. Physics and Chemistry of the Earth, Parts $A / B / C, 100,112-120$.

FAO. Soils resources, management and conservation service. (1983). Guidelines: Land evaluation for rainfed agriculture. FAO.

Gad, A. A. (2015). Land capability classification of some western desert Oases, Egypt, using remote sensing and GIS. The Egyptian Journal of Remote Sensing and Space Science, 18(1), S9-S18.

Hashim, Pm., Nayan, N., Saleh, Y., Mahat, H., Said, Z. M., \& Shiang, W. F. (2018). Water quality assessment of former Tin Mining Lakes for recreational purposes in Ipoh City, Perak, Malaysia. The Indonesian Journal of Geography, 50(1), 25-33. 
Helms, D. (1997). Land capability classification: The US experience. History of Soil Science: International Perspectives.

Kabanda, T. (2015). Land capability evaluation for crop production using remote sensing, GIS and geostatistics in Rietfontein, North West Province of South Africa. Geo Uerj, (26), 2-21.

Kanianska, R., Kizeková, M., Nováček, J., \& Zeman, M. (2014). Land-use and landcover changes in rural areas during different political systems: A case study of Slovakia from 1782 to 2006. Land Use Policy, 36, 554-566.

Kharche, V. K., \& Gaikawad, S. T. (1993). An appraisal of production potential of soils of Saongi watershed near Nagpur, Maharashtra. Agropedology, 3, 69-78.

Klingebiel, A. A., \& Montgomery, P. H. (1961). Land-capability classification. Soil Conservation Service, US Department of Agriculture.

Kumar, A., Mahapatra, S. K., Lal, T., Yadav, R. P., \& Singh, S. K. (2017). Land evaluation for land use planning towards sustainable crop production: A case study of Chhata tehsil in Mathura District, Uttar Pradesh, India. International Journal of Current Microbiology and Applied Sciences, 6(9), 859-870.

Lillesand, T., Kiefer, R. W., \& Chipman, J. (2015). Remote sensing and image interpretation. John Wiley \& Sons.

Liu, F., Chen, Y., Lu, H., \& Shao, H. (2017). Albedo indicating land degradation around the Badain Jaran Desert for better land resources utilization. Science of the Total Environment, 578, 67-73.

Mamat, L., Basri, N. E. A., Zain, S. M., \& Rahmah, E. (2016). Environmental sustainability indicators as impact tracker: A review. Journal of Sustainability Science and Management, 11(1), 29-42.

Maryati, S. (2013). Land capability evaluation of reclamation area in Indonesia coal mining using LCLP software. Procedia Earth And Planetary Science, 6, 465-473.

Mohd, Mohd Hairil Azman, F. N. U. R. U. Z., Jusoh, A., \& Rahman, M. A. A. (2019). Land slide suspectibility mapping at Lebir and Galas River Basins after extreme flood event using weights of evidence. Journal of Sustainability Science and Management, 14(2), 103-115.

Murphy, B. W., Murphy, C., Wilson, B. R., Emery, K. A., Lawrie, J., Bowman, G., ... Erskine, W. (2004). A revised land and soil capability classification for New South Wales. In 13th International Soil Conservation Organisation ConferenceBrisbane.

Osman, K. T. (2014). Soil degradation, conservation and remediation. Springer.

Panigrahy, S., Manjunath, K. R., \& Ray, S. S. (2005). Deriving cropping system performance indices using remote sensing data and GIS. International Journal of Remote Sensing, 26(12), 2595-2606.

Patel, N. R., Prasad, J., \& Kumar, S. (2001). Land capability assessment for land use planning using remote sensing and GIS. Agropedology, 2, 1-8.

Purwanto, A., \& Bayuardi, G. (2016). Monitoring the land use change in campus 2 STKIP PGRI Pontianak. Geoplanning: Journal of Geomatics and Planning, 3(1), 77-86.

Qiu, F., Chastain, B., Zhou, Y., Zhang, C., \& Sridharan, H. (2014). Modeling land suitability/capability using fuzzy evaluation. GeoJournal, 79(2), 167-182.

Rao, D. P., Gautam, N. C., Nagaraja, R., \& Mohan, P. R. (1996). IRS-1C applications in land use mapping and planning. Current Science, 575-581.

Razeena Beebi, P. M. (2015). Study of Midland Laterite Hill Ecosystem of Kasaragod District Kerala. Kannur University. 
Sholihah, N. A., Utomo, D. H., \& Juarti, J. (2016). Sifat fisika kimia Tanah Ordo Vertisol pada penggunaan lahan pertanian. Jurnal Pendidikan Geografi: Kajian, Teori, Dan Praktek Dalam Bidang Pendidikan Dan Ilmu Geografi, 21(1), 1-11.

Sinclair Jr, H. R., \& Dobos, R. R. (2006). Use of land capability classification system in the Surface Mining Control and Reclamation Act of 1977 (Public Law 95-87). PUBLIC $L A W, 95(87), 1$.

Skousen, J., \& Zipper, C. E. (2014). Post-mining policies and practices in the Eastern USA coal region. International Journal of Coal Science \& Technology, 1(2), 135-151.

Soil Conservation Service. (1958). Land capability classification. Washington, DC USDA -NRCS.

Soil Conservation Service. (1963). Know the capability of your land. Washington, DC: USDA -NRCS.

USDA. (1983). Soil Survey Manual. U.S. Department of Agriculture Handbook (18th ed.). Washington, D.C.: U.S. Government Printing Office.

Utomo, D. H. (2016). Morfologi Profil Tanah Vertisol di Kecamatan Kraton, Kabupaten Pasuruan. Jurnal Pendidikan Geografi, 21(2).

Widiati, R., Umami, N., \& Gunawan, T. (2017). Development of cattle farming as a model for sustainable rural development goal using spatial approach (Case in Southern Parts of Merapi Volcano Slope Sleman Regency of Yogyakarta). Indonesian Journal of Geography, 49(1), 80. https:// doi.org/10.22146/ijg.17299.

Zambon, I., Colantoni, A., Carlucci, M., Morrow, N., Sateriano, A., \& Salvati, L. (2017). Land quality, sustainable development and environmental degradation in agricultural districts: A computational approach based on entropy indexes. Environmental Impact Assessment Review, 64, 37-46. https://doi. org/10.1016/j.eiar.2017.01.003. 
